\title{
B cell-targeted therapies in autoimmunity: rationale and progress
} Paolo Fiorina and Mohamed H Sayegh*

\author{
Address: Transplantation Research Center, Children's Hospital and Brigham \& Women's Hospital, Harvard Medical School, 221 Longwood Ave, \\ Boston, MA 02115, USA \\ * Corresponding author: Mohamed H Sayegh (msayegh@rics.bwh.harvard.edu) \\ FI000 Biology Reports 2009, I:39 (doi:I0.34I0/BI-39)
}

The electronic version of this article is the complete one and can be found at: http://FI000.com/Reports/Biology/content/I/39

\begin{abstract}
$B$ cells are recognized as main actors in the autoimmune process. Autoreactive $B$ cells can arise in the bone marrow or in the periphery and, if not properly inhibited or eliminated, can lead to autoimmune diseases through several mechanisms: autoantibody production and immune complex formation, cytokine and chemokine synthesis, antigen presentation, $T$ cell activation, and ectopic lymphogenesis. The availability of agents capable of depleting B cells (that is, anti-CD20 and anti-CD22 monoclonal antibodies) or targeting B cell survival factors (atacicept and belimumab) opens new perspectives in the treatment of diseases such as systemic lupus erythematosus, rheumatoid arthritis, type I diabetes, and multiple sclerosis.
\end{abstract}

\section{Introduction and context}

$B$ cell depleting agents are currently available and the most used is definitely rituximab. Rituximab is a glycosylated immunoglobulin G (IgG) chimeric mouse/human antibody that binds to the CD20 antigen present on the majority of circulating B cells [1]. Expression of CD20 is restricted to the $\mathrm{B}$ cell lineage from the pre- $\mathrm{B}$-cell stage until terminal differentiation into plasma cells. Treatment with rituximab induces a notably rapid (within hours) and prolonged (more than 3 months) depletion of circulating B cells. Interestingly, naïve B cells appear to recover faster than memory B cells. The manner and speed of action of rituximab could potentially suggest an effect related to antibody-independent B cell function, whereas an antibody-mediated effect would not have been so fast since plasma cells are CD20-negative and thus not directly affected by rituximab [2]. Although this has been nicely demonstrated in autoimmune diseases, in the case of immune-mediated thrombocytopenia, Bussel [3] has defined three different phenotypic responses with very different kinetics of clinical response. In diseases such as pemphigus vulgaris, it has been clearly demonstrated that the mechanism of rituximab action is through eradication of the anti-keratinocyte IgG4 autoantibody [4]. However, many issues, such as the persistence of memory B cells or the ability of this drug to induce an in-depth depletion, remained to be defined.

\section{Major recent advances \\ $B$ cells and rheumatoid arthritis}

Significant evidence arising from experimental models indicates that autoantibodies play a key role in the pathogenesis of inflammatory arthritis; moreover, B cell depletion therapy with rituximab provides evidence that B cells play a major role in rheumatoid arthritis (RA) [5]. In addition to autoantibody production, B cells efficiently present antigen to $\mathrm{T}$ cells. Rheumatoid factor (RF)-producing $\mathrm{B}$ cells are particularly effective in presenting immune complexes to $\mathrm{T}$ cells [6]; they produce soluble factors, including cytokines and chemokines, that can modulate dendritic cell migration and function [7] and form tertiary or ectopic lymphoid tissue, which ranges from loose aggregates of $\mathrm{T}$ and $\mathrm{B}$ cells to distinct follicle-like structures in close contact with the synovial membrane of RA patients, amplifying autoimmune responses and inflammation [8].

\section{$B$ cells and systemic lupus erythematosus}

Systemic lupus erythematosus (SLE) is an autoimmune disease characterized by formation of pathogenic 
autoantibodies, immune complex deposition, and organ damage and failure [9]. A central role for B cells is evident and is confirmed by the therapeutic potential of $\mathrm{B}$ cell depleting treatment in humans [10,11]. Autoantibody production contributes to SLE development by inducing immune complex-mediated type III hypersensitivity and type II antibody-dependent cytotoxicity. Moreover, antibody deposition can instruct innate immune cells to produce pathogenic cytokines such as interferon-alpha (IFN $\alpha$ ), tumor necrosis factor (TNF), and interleukin-1 (IL-1) [12]. Several abnormalities of B cells have been related to an SLE-like phenotype; Bolland and colleagues [13] demonstrated how some of the genes involved in lupus may downregulate $\mathrm{B}$ cell receptor signaling at the immature stage, impairing B cell tolerance. Alterations in B cell longevity can also cause an SLE-like phonotype; transgenic expression of BAFF (B cell activator of the TNF family), a cytokine promoting B cell survival, leads to a lupus-like phenotype with high mature $\mathrm{B}$ cell and plasma cell numbers, spontaneous germinal center reactions, autoantibodies, and Ig deposition in the kidney [14]. Moreover, administration of soluble BAFF receptor ameliorates disease progression and survival; in human serum, elevated BAFF correlates with serum IgG and autoantibody levels [15] and excessive BAFF promotes the survival of autoreactive $\mathrm{B}$ cells in the periphery [16]. The breakdown of B cell tolerance occurs at a very early stage of development in both mice and humans [17] and may precede or trigger other immune abnormalities, as shown by the expression of antinuclear antibodies in SLE patients several years before the onset of clinical disease [18].

\section{B cells and type I diabetes}

Type 1 diabetes (T1D) is an autoimmune disease characterized by T-cell mediated destruction of insulinproducing pancreatic $\beta$ cells [19]. T1D involves the interaction of different subsets of lymphocytes and antigen-presenting cells; in particular, B lymphocytes, because of their highly efficient ability to internalize $\beta$ cell antigens through Ig and subsequently present them to autoreactive CD4 T-cells, they serve as a preferential subset of diabetogenic antigen-presenting cells in nonobese diabetic (NOD) mice and possibly in humans [20]. Indeed, B cell-deficient NOD mice have been shown to be protected from autoimmune diabetes [21] and to be deficient in the development of the major autoantigen T-cell response (such as glutamate decarboxylase) [22]. These findings have made $\mathrm{B}$ cell targeting a new and attractive strategy for the treatment of T1D. Work by $\mathrm{Hu}$ and colleagues [23] showed the positive effects of an anti-CD20-based B cell depleting strategy, preventing autoimmune diabetes and reversing established diabetes, in transgenic NOD mice expressing the humanized CD20 receptor on B cells. The actual use of $\mathrm{B}$ cell depletion as a therapy for human autoimmune disease, including its use in patients with new-onset T1D, is ongoing [24]. Recent work by our group suggested a novel approach: a newly developed reagent, anti-CD22 calicheamicin-conjugated monoclonal antibody (mAb) [25], which has been previously tested in humans, both for the immunoregulatory properties of CD22 engagement and for the possibility of depleting mature B cells. It has had promising results in the fields of autoimmune disease [26] and B cell malignancies [27], but had not been tested in diabetes until recently. The study shows how anti-CD22 calicheamicin-conjugated mAb treatment can delay diabetes onset in prediabetic NOD mice and, more importantly, can restore normoglycemia in new-onset hyperglycemic NOD mice. Moreover, for the very first time, data highlight that re-emerging B cells in NOD mice display a different phenotype from naïve $\mathrm{B}$ cells; they are functionally impaired in their ability to present antigen and can regulate the autoimmune response, resulting in long-term tolerance to autoantigens in vivo [25].

\section{$B$ cells and multiple sclerosis}

In addition to $\mathrm{T}$ cell responses, $\mathrm{B}$ cell and antibody responses may contribute to the pathogenesis of multiple sclerosis (MS) [28]. Antimyelin autoantibodies such as those directed against myelin basic protein and myelin oligodendrocyte glycoprotein can target damage in both animal and human inflammatory central nervous system diseases [29]. B cells are also able to internalize and present antigens through the $\mathrm{B}$ cell receptor at least 10,000 times more efficiently than professional antigen-presenting cells, and can activate T cells, produce cytokines such as IL- 6 and IL-10 that affect the local environment, play a role in the formation and maintenance of lymphoid-like follicles in the ventricular-meningeal compartment [30], and harbor the Epstein-Barr virus in a chronically activated state.

\section{Future directions}

New approaches to targeting the B cell compartment are under investigation. Trials with anti-CD20 mAbs have been published recently in MS [2], RA [5], and SLE $[10,11]$ and should be published soon for T1D. Whereas anti-CD20 therapy for MS and RA has been successful, many limitations appear to be evident when it is used for SLE and T1D, possibly due to the presence of highly specialized memory B cells resistant to depletion, or to the potential inability of anti-CD20 to deplete B cells in the pancreas or in tertiary lymphoid tissue.

None of the published trials for SLE are controlled, and work presented at the 2008 American College of 
Rheumatology annual meeting showed negative data from a placebo-controlled trial on the use of rituximab in nonrenal SLE (EXPLORER). Thus, another negative trial of rituximab in lupus nephritis (LUNAR) would suggest that anti-CD20 mAb might be inefficacious in human SLE.

Therefore, there is a need for new agents targeting memory B cells/plasma cells and agents selective for autoreactive B cells. Selective modulation of B cells has been achieved recently with a humanized mAb against the B cell surface marker CD22. This antibody (epratuzumab) has been reported to be effective, with the same safety profile, in two prototype autoimmune diseases, SLE and primary Sjögren syndrome [31,32]. Other drugs, such as atacicept (a fully human recombinant fusion protein that blocks the activity of B-lymphocyte stimulator [BLyS] and of a proliferation-inducing ligand [APRIL]) and belimumab (LymphoStat- ${ }^{\circledR}{ }^{\circledR}$, a human $\mathrm{mAb}$ that specifically recognizes and inhibits the biological activity of BLyS), inhibit specific B cell survival factors, resulting in reductions in B cells and plasma cells [33]. These drugs are undergoing clinical evaluation in phase II and III studies in patients with relapsing MS, SLE, lupus nephritis, RA, and several B cell malignancies. The use of these drugs induces a reversible decrease in circulating Ig concentration and a reduction in mature B cells in the peripheral blood and lymphoid tissues [34]. Unfortunately, the lupus nephritis trial involving atacicept was stopped earlier this year due to increased frequency of severe infections. The other studies of atacicept in SLE, RA, and MS are proceeding. For the sake of completeness, we would like to mention the development of anti-CD19 mAbs, as well as the single-chain CD20-binding polypeptides that are being co-developed by Trubion Pharmaceuticals Inc (Seattle, WA, USA) and Wyeth (Madison, NJ, USA). Finally, a lupus trial using abetimus (a double-stranded oligodeoxyribonucleotide thylene glycol that was developed to induce tolerance in B cells directed against double-stranded DNA) was recently stopped because of an interim analysis showing futility.

Two recent papers show a new regulatory role for specific subsets of B cells in MS and T1D, confirming that B cells can abrogate $\mathrm{T}$ cell immune response when co-adoptively transfered with autoreactive $\mathrm{T}$ cells or can halt disease progression [25,35].

The paper from Tedder and colleagues [35] showed that $\mathrm{B}$ cells play critical positive and negative regulatory roles in a murine model of MS [experimental autoimmune encephalomyelitis (EAE)]. B cell depletion had two opposing effects on disease [35]. Early B cell depletion exacerbated not only EAE induction, but also the recovery phase of disease [35]. Moreover, the adoptive transfer of IL-10-producing regulatory B10 cells, but not other B cells, normalized EAE pathogenesis [35]. Therefore, investigators proposed that increased EAE severity following total B cell depletion before disease induction results from depletion of the B10-cell subset [35]. Regulatory B cells may be critical during disease induction and for resolving disease. In contrast, B cell depletion after the onset of EAE symptoms ameliorated disease progression [35], making this strategy applicable for treating human MS after disease onset.

Anti-CD20 mAb treatment depletes memory cells in mice but does not deplete long-lived plasma cells [32]. Thus, CD $20^{+}$B-cell depletion may be most beneficial when carried out before the long-lived plasma cell pool is established.

Therefore, future studies will investigate selectivity and specific depletion/targeting of autoreactive B cells and expansion of regulatory B cells.

\section{Abbreviations}

APRIL, a proliferation-inducing ligand; BAFF, B cell activator of the tumor necrosis factor family; BLyS, B-lymphocyte stimulator; EAE, experimental autoimmune encephalomyelitis; EXPLORER, a randomized, doubleblind, placebo controlled, multicenter, phase II/III study to evaluate the efficacy and safety of rituximab in subjects with moderate to severe SLE; Ig, immunoglobulin; $\mathrm{IL}$, interleukin; IFN $\alpha$, interferon-alpha; LUNAR, a phase III, randomized, double-blind, placebo-controlled, multi-center study to evaluate the efficacy and safety of rituximab in subjects with class III or IV lupus nephritis; $\mathrm{mAb}$, monoclonal antibody; MS, multiple sclerosis; NOD, nonobese diabetic; RA, rheumatoid arthritis; $\mathrm{RF}$, rheumatoid factor; SLE, systemic lupus erythematosus; T1D, type 1 diabetes; TNF, tumor necrosis factor.

\section{Competing interests}

The authors declare that they have no competing interests.

\section{Acknowledgments}

We would like to acknowledge support from a pilot and feasibility award from the Boston Area Diabetes Endocrinology Research Center (5P30DK57521). Paolo Fiorina is the recipient of an American Society of Transplantation - Juvenile Diabetes Research Foundation (AST-JDRF) Faculty Grant and a JDRF-Career Development Award. 


\section{References}

I. Stashenko P, Nadler LM, Hardy R, Schlossman SF: Characterization of a human B lymphocyte-specific antigen. J Immunol 1980, 125: | 678-85.

2. Bar-Or A, Calabresi PA, Arnold D, Markowitz C, Shafer S, Kasper LH, Waubant E, Gazda S, Fox RJ, Panzara M, Sarkar N, Agarwal S, Smith $\mathrm{CH}$ : Rituximab in relapsing-remitting multiple sclerosis: a 72-week, open-label, phase I trial. Ann Neurol 2008, 63:395-400.

3. Bussel J: Treatment of immune thrombocytopenic purpura in adults. Semin Hematol 2006, 43:S3-10; discussion SI8-19.

4. Joly $\mathrm{P}$, D'Incan M, Musette P: Rituximab for pemphigus vulgaris. N Engl J Med 2007, 356:52I; author reply 52I-2.

5. Higashida J, Wun T, Schmidt S, Naguwa SM, Tuscano JM: Safety and efficacy of rituximab in patients with rheumatoid arthritis refractory to disease modifying antirheumatic drugs and anti-tumor necrosis factor-alpha treatment. J Rheumatol 2005, 32:2109-15.

6. Roosnek E, Lanzavecchia A: Efficient and selective presentation of antigen-antibody complexes by rheumatoid factor $B$ cells. J Exp Med 1991, 173:487-9.

7. Kaser A, Dunzendorfer S, Offner FA, Ludwiczek O, Enrich B, Koch RO, Cruikshank WW, Wiedermann C], Tilg H: B lymphocytederived IL-I 6 attracts dendritic cells and Th cells. J Immunol 2000, I 65:2474-80.

8. Takemura S, Braun A, Crowson C, Kurtin PJ, Cofield RH, O'Fallon WM, Goronzy J], Weyand CM: Lymphoid neogenesis in rheumatoid synovitis. J Immunol 200I, 167:1072-80.

FI000 Factor 3.0 Recommended

Evaluated by Reina Mebius 24 Jan 2002

9. Braun A, Sis J, Max R, Mueller K, Fiehn C, Zeier M, Andrassy K: Antichromatin and anti-C Iq antibodies in systemic lupus erythematosus compared to other systemic autoimmune diseases. Scand J Rheumatol 2007, 36:291-8.

10. Leandro MJ, Edwards JC, Cambridge G, Ehrenstein MR, Isenberg DA: An open study of $B$ lymphocyte depletion in systemic lupus erythematosus. Arthritis Rheum 2002, 46:2673-7.

II. Looney RJ, Anolik JH, Campbell D, Felgar RE, Young F, Arend LJ, Sloand JA, Rosenblatt J, Sanz I: B cell depletion as a novel treatment for systemic lupus erythematosus: a phase I/II doseescalation trial of rituximab. Arthritis Rheum 2004, 50:2580-9.

12. Martin F, Chan AC: Pathogenic roles of $\mathbf{B}$ cells in human autoimmunity; insights from the clinic. Immunity 2004, 20:5 I7-27.

13. Bolland S, Ravetch JV: Spontaneous autoimmune disease in Fc(gamma)RIIB-deficient mice results from strain-specific epistasis. Immunity 2000, I3:277-85

14. Gross JA, Johnston J, Mudri S, Enselman R, Dillon SR, Madden K, Xu W, Parrish-Novak J, Foster D, Lofton-Day C, Moore M, Littau A, Grossman A, Haugen $H$, Foley K, Blumberg $H$, Harrison K, Kindsvogel W, Clegg CH: TACI and BCMA are receptors for a TNF homologue implicated in B-cell autoimmune disease. Nature 2000, 404:995-9.

15. Stohl W, Metyas S, Tan SM, Cheema GS, Oamar B, Xu D, Roschke V, Wu Y, Baker KP, Hilbert DM: B lymphocyte stimulator overexpression in patients with systemic lupus erythematosus: Iongitudinal observations. Arthritis Rheum 2003, 48:3475-86.

16. Thien M, Phan TG, Gardam S, Amesbury M, Basten A, Mackay F, Brink R: Excess BAFF rescues self-reactive $B$ cells from peripheral deletion and allows them to enter forbidden follicular and marginal zone niches. Immunity 2004, 20:785-98.

17. Yurasov S, Wardemann H, Hammersen J, Tsuiji M, Meffre E, Pascual V, Nussenzweig MC: Defective B cell tolerance checkpoints in systemic lupus erythematosus. J Exp Med 2005, 20 I:703-I I.

18. Arbuckle MR, McClain MT, Rubertone MV, Scofield RH, Dennis GJ, James JA, Harley JB: Development of autoantibodies before the clinical onset of systemic lupus erythematosus. $N$ Engl I Med 2003, 349: I526-33.
19. Atkinson MA, Eisenbarth GS: Type I diabetes: new perspectives on disease pathogenesis and treatment. Lancet 200I, 358:22I-9.

20. Wong FS, Wen L, Tang M, Ramanathan M, Visintin I, Daugherty J, Hannum LG, Janeway CA Jr, Shlomchik MJ: Investigation of the role of B-cells in type I diabetes in the NOD mouse. Diabetes 2004, 53:258I-7.

21. Serreze DV, Chapman HD, Varnum DS, Hanson MS, Reifsnyder PC, Richard SD, Fleming SA, Leiter EH, Shultz LD: B lymphocytes are essential for the initiation of $T$ cell-mediated autoimmune diabetes: analysis of a new "speed congenic" stock of NOD. Ig mu null mice. J Exp Med 1996, I 84:2049-53.

22. Serreze DV, Silveira PA: The role of B lymphocytes as key antigen-presenting cells in the development of $T$ cellmediated autoimmune type I diabetes. Curr Dir Autoimmun 2003, 6:212-27.

23. Hu CY, Rodriguez-Pinto D, Du W, Ahuja A, Henegariu O, Wong FS, Shlomchik MJ, Wen L: Treatment with CD20-specific antibody prevents and reverses autoimmune diabetes in mice. J Clin Invest 2007, I I 7:3857-67.

FI000 Factor 3.0 Recommended

Evaluated by Mark Atkinson 17 Dec 2007

24. Skyler JS: Prediction and prevention of type I diabetes: progress, problems, and prospects. Clin Pharmacol Ther 2007. 8I:768-7I.

25. Fiorina $P$, Vergani $A$, Dada S, Jurewicz $M$, Wong $M$, Law K, Wu E, Tian Z, Abdi R, Guleria I, Rodig S, Dunussi-Joannopoulos K, Bluestone J, Sayegh $\mathrm{MH}$ : Targeting $\mathbf{C D 2 2}$ reprograms B-cells and reverses autoimmune diabetes. Diabetes 2008, 57:30I3-24.

26. Nitschke L, Tsubata T: Molecular interactions regulate $\mathbf{B C R}$ signal inhibition by CD22 and CD72. Trends Immunol 2004, 25:543-50.

27. Coleman M, Goldenberg DM, Siegel AB, Ketas JC, Ashe M, Fiore JM, Leonard JP: Epratuzumab: targeting B-cell malignancies through CD22. Clin Cancer Res 2003, 9:399IS-3994S.

28. Archelos JJ, Storch MK, Hartung HP: The role of $\mathbf{B}$ cells and autoantibodies in multiple sclerosis. Ann Neurol 2000, 47:694706.

29. Genain CP, Cannella B, Hauser SL, Raine CS: Identification of autoantibodies associated with myelin damage in multiple sclerosis. Nat Med 1999, 5: I70-5

30. Serafini B, Rosicarelli B, Magliozzi R, Stigliano E, Aloisi F: Detection of ectopic B-cell follicles with germinal centers in the meninges of patients with secondary progressive multiple sclerosis. Brain Pathol 2004, I4: I64-74.

31. Steinfeld SD, Tant L, Burmester GR, Teoh NK, Wegener WA, Goldenberg DM, Pradier O: Epratuzumab (humanised antiCD22 antibody) in primary Sjogren's syndrome: an openlabel phase I/II study. Arthritis Res Ther 2006, 8:RI29.

32. Dorner T, Kaufmann J, Wegener WA, Teoh N, Goldenberg DM, Burmester GR: Initial clinical trial of epratuzumab (humanized anti-CD22 antibody) for immunotherapy of systemic lupus erythematosus. Arthritis Res Ther 2006, 8:R74

33. Menge T, Weber MS, Hemmer B, Kieseier BC, von Budingen HC, Warnke C, Zamvil SS, Boster A, Khan O, Hartung HP, Stuve O: Disease-modifying agents for multiple sclerosis: recent advances and future prospects. Drugs 2008, 68:2445-68.

34. Ponce R: Preclinical support for combination therapy in the treatment of autoimmunity with atacicept. Toxicol Pathol 2009, 37:89-99.

35. Matsushita T, Yanaba K, Bouaziz JD, Fujimoto M, Tedder TF: Regulatory B cells inhibit EAE initiation in mice while other B cells promote disease progression. J Clin Invest 2008, I | 8:3420-30.

FI000 Factor 3.0 Recommended Evaluated by Noel Rose 17 Oct 2008 